\begin{tabular}{|l|l|l||}
\hline \multicolumn{2}{|c|}{ PublisherInfo } \\
\hline \hline PublisherName & $:$ & BioMed Central \\
\hline \hline PublisherLocation & $:$ & London \\
\hline \hline PublisherImprintName & $:$ & BioMed Central \\
\hline \hline
\end{tabular}

\title{
Mapping recombination
}

\begin{tabular}{|l|l|l||}
\hline \multicolumn{2}{|c|}{ ArticleInfo } \\
\hline \hline ArticleID & $:$ & 3802 \\
\hline \hline ArticleDOI & $:$ & $10.1186 /$ gb-spotlight-20001018-02 \\
\hline \hline ArticleCitationID & $:$ & spotlight-20001018-02 \\
\hline \hline ArticleSequenceNumber & $:$ & 239 \\
\hline \hline ArticleCategory & $:$ & Research news \\
\hline \hline ArticleFirstPage & $:$ & 1 \\
\hline \hline ArticleLastPage & $:$ & 2 \\
\hline \hline & $:$ & RegistrationDate : 2000-10-18 \\
ArticleHistory & $:$ & OnlineDate $\quad$ 2000-10-18 \\
\hline \hline ArticleCopyright & $:$ & BioMed Central Ltd2000 \\
\hline \hline ArticleGrants & $:$ & \\
\hline \hline ArticleContext & $:$ & 130591111 \\
\hline \hline
\end{tabular}




\section{William Wells}

Email: wells@biotext.com

In the October 10 Proceedings of the National Academy of Sciences Gerton et al. use arrays to map hotspots and coldspots of meiotic recombination across the whole yeast genome (Proc Natl Acad Sci USA 2000, 97:11383-11390). They isolate DNA from sporulating cells that are mutant in rad50S, and therefore blocked with the recombination protein Spo11p covalently bound to DNA. The DNA fragments that are covalently linked to proteins (with Spo11p presumably predominant) are trapped using a glass filter, and used as probes in an array experiment to identify recombination sites. Hotspots are denser and more active on smaller chromosomes, and are often associated with peaks of high $\mathrm{G}+\mathrm{C}$ content. Metabolic genes, which have high transcriptional activity, are over-represented. As in previous studies, coldspots are associated with telomeres and centromeres.

\section{References}

1. Proceedings of the National Academy of Sciences, [http://www.pnas.org/]

2. Meiosis-specific DNA double-strand breaks are catalyzed by Spo11, a member of a widely conserved protein family. 